\title{
Delayed C5 Palsy after Laminectomy and Fusion for Ossification of the Posterior Longitudinal Ligament
}

\section{Darryl Lau and Paul Park*}

Department of Neurosurgery, University of Michigan Medical School, Ann Arbor, MI, USA

\begin{abstract}
Ossification of the posterior longitudinal ligament (OPLL) can cause myelopathy. Laminectomy with fusion is one surgical option for the treatment of symptomatic OPLL. In this report, we present 2 illustrative cases of unilateral C5 palsy occurring in a delayed manner after posterior decompression for OPLL. Both patients were successfully treated with conservative management. incidence, potential etiology, management and outcomes for this potentially debilitating complication are reviewed.
\end{abstract}

Keywords: C5 palsy; Cervical spine; Complication; OPLL; Ossification; Posterior longitudinal ligament; Surgery

\section{Introduction}

The etiology of ossification of the posterior longitudinal ligament (OPLL) is multifactorial and involves complex genetic and environmental factors $[1,2]$. If left untreated, ossification can progress markedly [3] and when compression of $20-40 \%$ of the spinal cord occurs, myelopathy can develop [4]. The current mainstay treatment for symptomatic OPLL is surgical, while conservative methods are less successful [5]. A variety of surgical approaches including corpectomy, laminectomy, laminoplasty and laminectomy with fusion have been used to treat symptomatic cervical OPLL. In this article, we present 2 cases of delayed C5 palsy after multilevel cervical laminectomy and fusion. Patient management and outcomes are reported, as well as a review of the literature with regard to the incidence, etiology, management and outcomes of this potential complication in OPLL patients.

\section{Case Illustrations}

\section{Patient 1}

A 54-year-old woman with a history of diabetes presented with progressive gait abnormality, hand dysfunction and urinary incontinence. She reported multiple falls due to gait imbalance and difficulty with tasks requiring manual dexterity such as buttoning shirts. Physical examination was most notable for mild weakness of the proximal leg muscles, diffuse sensory loss in her right leg and a widebased unsteady gait. Imaging revealed high-grade cervical stenosis attributed to OPLL (Figure 1). Of note, there was also significant thoracic stenosis from OPLL and ossification of the ligamentum flavum. The patient underwent C3-7 laminectomies with bilateral C4-5 and C5-6 foraminotomies in conjunction with $\mathrm{C} 3-\mathrm{T} 1$ posterior instrumented fusion. Multimodality neurophysiologic monitoring including somatosensory evoked potentials, transcranial motor evoked potentials and continuous electromyography was used during the operation without any significant changes noted. She also underwent posterior thoracic decompression complicated by durotomy. Postoperatively, the patient was noted to have a stable neurologic examination. Computed tomography (CT) was performed and showed adequate bony decompression and appropriate placement of instrumentation. The patient's course was uneventful until postoperative day (POD) 6 , when she developed weakness of her left deltoid (Medical Research Council [MRC] grade 2/5). A course of steroids was then administered. On POD 7, the patient was noted to have biceps weakness (MRC grade 3/5). Further decompressive surgery from an anterior approach was discussed as an option; however, the patient declined. She was subsequently discharged and underwent extensive physical therapy. At a 4-month follow-up visit, the patient's biceps strength had improved to MRC grade 4/5. At 7-month follow-up, her deltoid strength was MRC grade 3/5. At 1-year follow-up, her deltoid strength was MRC grade $4+/ 5$ and biceps was MRC grade 5/5. The patient did not note any arm dysfunction. Her gait had returned to normal and bladder dysfunction had resolved.

\section{Patient 2}

A 53-year-old woman presented with history of a fall due to gait imbalance. She also reported "spasms" of her extremities, paresthesias and loss of manual dexterity. Her physical examination was notable for increased tone, hyperreflexia, non-sustained clonus, mild
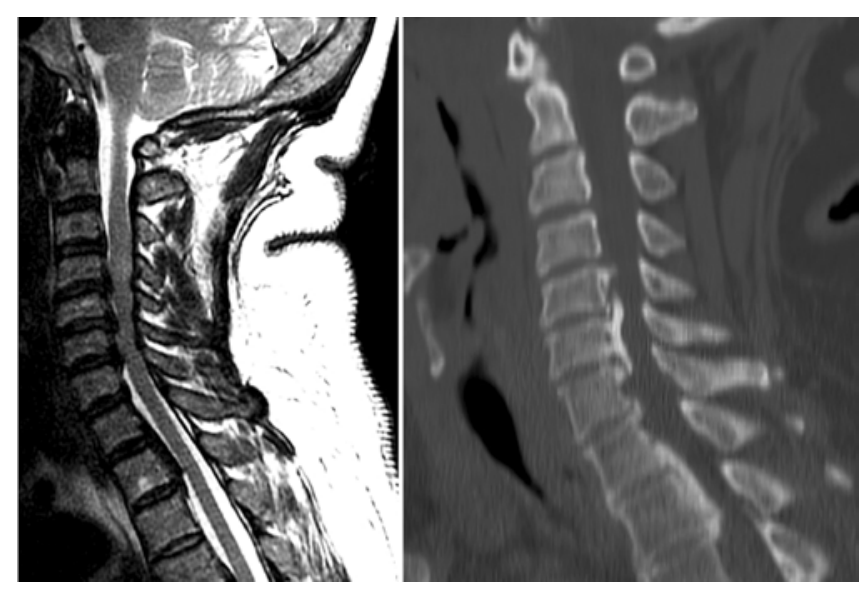

Figure 1: Sagittal T2-weighted MRI showing multilevel cervical stenosis from OPLL (left), and sagittal reformatted CT showing ossification of posterior longitudinal ligament (right).

*Corresponding author: Paul Park, Department of Neurosurgery, University of Michigan Health System, 1500 E Medical Center Drive, Room 3552 TC, Ann Arbor MI 48109-5338, Tel: 734-615-2627; Fax: 734-936-9294; E-mail: ppark@umich.edu

Received December 03, 2011; Accepted December 14, 2011; Published December 18, 2011

Citation: Lau D, Park P (2012) Delayed C5 Palsy after Laminectomy and Fusion for Ossification of the Posterior Longitudinal Ligament. J Spine 1:104. doi:10.4172/2165-7939.1000104

Copyright: () 2012 Lau D, et al. This is an open-access article distributed under the terms of the Creative Commons Attribution License, which permits unrestricted use, distribution, and reproduction in any medium, provided the original author and source are credited. 
weakness of hand intrinsics and unsteady gait. Cervical MRI revealed multilevel stenosis with findings consistent with OPLL (Figure 2). The patient underwent a C2-7 laminectomy in conjunction with C2-T1 instrumented fusion. Multimodality neurophysiologic monitoring was used without significant changes noted. Postoperatively, the patient had a stable neurologic examination.

On POD 3, the patient developed left deltoid weakness (MRC grade 1/5). A course of steroids was instituted. MRI was performed and showed adequate decompression (Figure 3). On POD 5, the patient developed left biceps weakness (MRC grade 2/5). The patient was discharged and underwent extensive physical therapy. At her 5-month follow-up visit, there was significant improvement in left biceps strength (MRC grade 4/5); however, her left deltoid remained weak (MRC grade 2/5). Further physical therapy was prescribed. At her 10-month follow-up visit, left deltoid function had improved to MRC grade $4 / 5$.

\section{Discussion}

OPLL is most commonly seen in Asia and in people of Asian descent [5], which is consistent with multiple studies suggesting a genetic component $[2,6,7]$. OPLL commonly develops in the cervical spine and can lead to neurologic symptoms [8]. In the setting of an appropriate clinical picture, the diagnosis of OPLL can be made via MRI, preferably of the whole spine [9]. As seen in Patient 1, other areas of stenosis can occur. While surgical decompression is the mainstay treatment for OPLL, there are currently few prognostic factors that are useful in predicting complications and postoperative outcomes [10,11]. Reported surgical complications of cervical decompression for OPLL include durotomy causing cerebrospinal fluid leak [12], spinal epidural hematoma formation [13], spinal cord herniation [14], rare bilateral phrenic nerve palsy [15] and vertebral artery injury [16].

C5 palsy occurring after surgical decompression for OPLL has been reported (Table 1). Incidence ranges from $2.6 \%$ to $18.4 \%$ and onset typically is delayed, ranging from 4 hours to 7 days [5,16-19]. Unilateral or bilateral palsies are possible [5]. Given the delayed nature of the

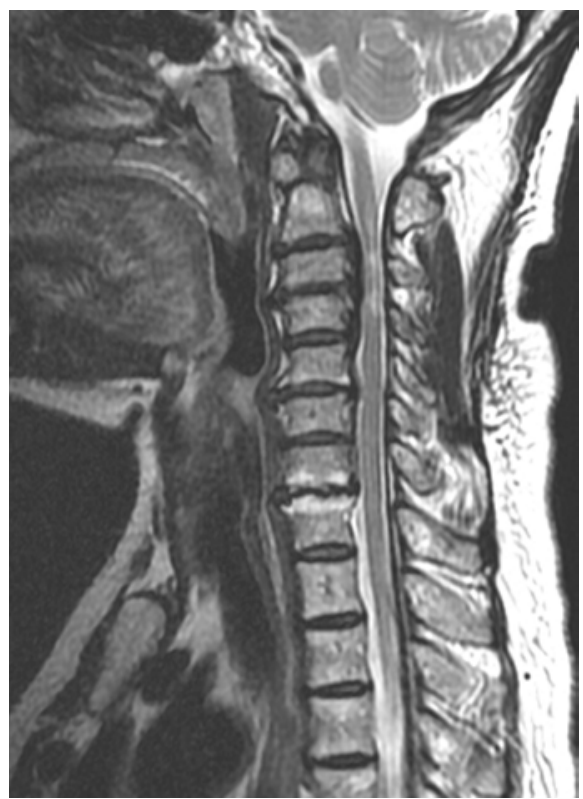

Figure 2: Sagittal T2-weighted MRI showing multilevel cervical stenosis from OPLL.

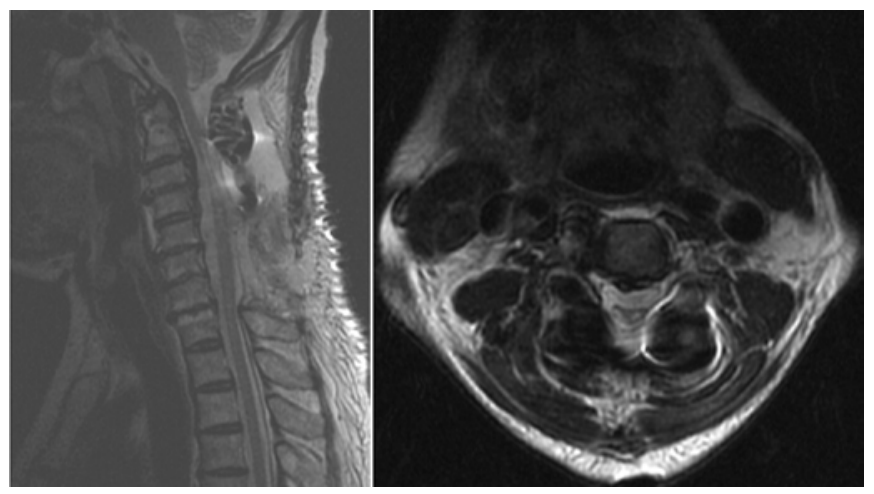

Figure 3: Sagittal T2-weighted MRI showing adequate central decompression (left), and axial T2-weighted MRI showing no central and only mild foraminal stenosis at C4-5 (right).

condition, an intraoperative iatrogenic injury is not typically considered causative. The most commonly cited theory for the pathogenesis of delayed C5 palsies involves spinal cord shifting and spinal nerve tethering [20-22]. However, this theory remains controversial in the current literature $[23,24]$. Anatomically, C5 is a relatively short spinal nerve and has a more horizontal take-off compared to other spinal nerves in the cervical region, which predisposes the C5 spinal nerve to tethering after posterior decompression [5]. Laminectomy allows the spinal cord to displace posteriorly and potentially cause a "stretch injury," with C5 preferentially affected due to its length [25-27]. In addition, restoration of cervical lordosis can increase the tethering effect and possibly result in a higher chance of nerve root palsy [17]. Since delayed C5 palsy has also been reported after anterior decompression, other potential etiologies have been suggested.

Another theory to the pathogenesis of postoperative delayed palsies consists of brachial neuritis occurring after cervical spine surgery. Significant stress as can occur from surgery may induce reactivation of a latent infection causing brachial neuritis and resulting in a delayed cervical palsy [28]. This mechanism parallels the pathogenesis of delayed facial nerve palsies reported after craniotomies [29], which include speculation that the complication results from reactivation of a latent herpes simplex virus [30]. It has also been suggested that cauterization of small blood vessels during surgery can lead to ischemia of nervous tissue [26] due to an inadequate blood supply. Local reperfusion has been proposed as a mechanism of additional injury leading to deterioration of spinal cord grey matter [31,32], which predisposes patients to developing postoperative palsies [33].

While there is no standard treatment for delayed C5 palsy, a conservative regimen including neurotrophy drugs, high-pressure oxygen therapy and physical therapy has been advocated [5,17]. Persistent stenosis, particularly impacting the C5 nerve root, may be an indication for further surgery; however, outcomes are unclear. A conservative approach appears to be the main treatment modality used in cases of C5 palsy and the majority of patients appear to improve significantly, as evidenced in Table 1.

In the cases presented, both patients developed a delayed unilateral C5 palsy, occurring on the sixth and third day after surgery, respectively. No adverse intraoperative events were noted. Multimodality neurophysiologic monitoring was used without any significant changes noted, suggesting that an immediate iatrogenic event did not occur. Foraminotomies, which were performed in Patient 1, did not prevent occurrence of the C5 palsy. A specific etiology in 
Citation: Lau D, Park P (2012) Delayed C5 Palsy after Laminectomy and Fusion for Ossification of the Posterior Longitudinal Ligament. J Spine 1:104. doi:10.4172/2165-7939.1000104

Page 3 of 4

\begin{tabular}{|c|c|c|c|c|}
\hline Author & Incidence & Procedure & Treatment & Outcome \\
\hline Chen et al. [17] & $18.4 \%(9 / 49)$ & $\begin{array}{l}\text { Laminectomy with lateral mass } \\
\text { screw fixation }\end{array}$ & $\begin{array}{l}\text { Rehabilitation therapy (functional } \\
\text { exercise), high-pressure oxygen }\end{array}$ & $\begin{array}{l}2 \text { patients recovered in } 4-6 \text { months; } 7 \text { patients } \\
\text { required } 1 \text { year }\end{array}$ \\
\hline Chen et al. [5] & $\begin{array}{l}14.3 \%(4 / 28) \\
\text { Laminectomy } \\
8.0 \%(2 / 25) \\
\text { Laminoplasty } \\
0.0 \%(0 / 22) \text { Anterior } \\
\text { corpectomy }\end{array}$ & $\begin{array}{l}\text { Laminectomy with fusion, } \\
\text { laminoplasty, or corpectomy }\end{array}$ & $\begin{array}{l}\text { Neurotrophy drugs, high-pressure } \\
\text { oxygen, functional exercise }\end{array}$ & $\begin{array}{l}\text { Significant recovery in all patients at } 6 \text { months to } \\
1 \text { year }\end{array}$ \\
\hline $\begin{array}{l}\text { Ikenaga et al. } \\
{[18]}\end{array}$ & $7.3 \%(10 / 137)$ & $\begin{array}{l}\text { Anterior decompression } \\
\text { (discectomy or partial corpectomy) }\end{array}$ & $\begin{array}{l}\text { Conservative treatment (not further } \\
\text { specified) }\end{array}$ & $\begin{array}{l}\text { Incomplete recovery in } 4 \text { patients; full recovery in } \\
\text { remaining } 6 \text { patients }\end{array}$ \\
\hline $\begin{array}{l}\text { Kaneko et al. } \\
{[33]}\end{array}$ & $9.1 \%(2 / 22)$ & Laminoplasty & Treatment not specified & $\begin{array}{l}1 \text { patient recovered within } 3 \text { months; } 1 \text { patient had } \\
\text { no improvement at } 2 \text { years }\end{array}$ \\
\hline Seichi et al. [16] & $2.8 \%(16 / 581)$ & Laminoplasty & Treatment not specified & $\begin{array}{l}1 \text { patient had minimal recovery, } 2 \text { patients had } \\
\text { partial recovery, and } 13 \text { patients had full recovery } \\
\text { at } 6 \text { months }\end{array}$ \\
\hline
\end{tabular}

Table 1: Studies reporting C5 palsies after treatment of cervical OPLL.

either case was not identified and potentially could have occurred from a "tethering" phenomenon, ischemia, or brachial neuritis. Both patients were treated successfully with extensive physical therapy. Any signs of improvement, however, did not occur for at least several months and meaningful recovery was evident at 1 year for Patient 1 and 10 months for Patient 2. Affected patients should therefore be counseled that recovery may take many months.

\section{Conclusion}

Delayed C5 palsy is a potential complication after decompressive surgery for OPLL. Various etiologies have been proposed including a "tethering" phenomenon, vascular insult and brachial neuritis. Regardless of etiology, the most commonly reported treatment has been conservative, with the majority of patients reporting improvement of symptoms.

\section{Disclosures/Funding}

The authors report no conflict of interest concerning the materials used in this study or the findings specified in this case report. No financial support was received pertaining to generation of this study.

\section{References}

1. Inamasu J, Guiot BH, Sachs DC (2006) Ossification of the posterior longitudinal ligament: an update on its biology, epidemiology, and natural history. Neurosurgery 58: 1027-1039.

2. Stetler WR, La Marca F, Park P (2011) The genetics of ossification of the posterior longitudinal ligament. Neurosurg Focus 30: E7.

3. Murakami M, Seichi A, Chikuda H, Takeshita K, Nakamura K, et al. (2010) Longterm follow-up of the progression of ossification of the posterior longitudinal ligament. J Neurosurg Spine 12: 577-579.

4. Kato Y, Kanchiku T, Imajo Y, Kimura K, Ichihara K, et al. (2010) Biomechanical study of the effect of degree of static compression of the spinal cord in ossification of the posterior longitudinal ligament. J Neurosurg Spine 12: 301 305.

5. Chen Y, Guo Y, Lu X, Chen D, Song D, et al. (2011) Surgical strategy for multilevel severe ossification of posterior longitudinal ligament in the cervical spine. J Spinal Disord Tech 24: 24-30.

6. Chung WS, Nam DH, Jo DJ, Lee JH (2011) Association of toll-like receptor 5 gene polymorphism with susceptibility to ossification of the posterior longitudinal ligament of the spine in korean population. J Korean Neurosurg Soc 49: 8-12.

7. Stapleton CJ, Pham MH, Attenello FJ, Hsieh PC (2011) Ossification of the posterior longitudinal ligament: genetics and pathophysiology. Neurosurg Focus 30: E6.

8. Matsumoto M, Chiba K, Toyama Y, Takeshita K, Seichi A, et al. (2008) Surgical results and related factors for ossification of posterior longitudinal ligament of the thoracic spine: a multi-institutional retrospective study. Spine (Phila Pa 1976) 33: 1034-1041.

9. Guo JJ, Yang HL, Cheung KM, Tang TS, Luk KD (2009) Classification and management of the tandem ossification of the posterior longitudinal ligament and flaval ligament. Chin Med J (Engl) 122: 219-224.

10. Inamasu J, Guiot BH (2009) Factors predictive of surgical outcome for ossification of the posterior longitudinal ligament of the cervical spine. J Neurosurg Sci 53: 93-100.

11. Li H, Jiang LS, Dai LY (2008) A review of prognostic factors for surgical outcome of ossification of the posterior longitudinal ligament of cervical spine. Eur Spine J 17: 1277-1288.

12. Mizuno J, Nakagawa $\mathrm{H}$ (2001) Outcome analysis of anterior decompressive surgery and fusion for cervical ossification of the posterior longitudinal ligament: report of 107 cases and review of the literature. Neurosurg Focus 10: E6.

13. Yamazaki M, Okawa A, Fujiyoshi T, Kawabe J, Furuya T, et al. (2010) Intraoperative spinal subarachnoid hematoma in a patient with cervical ossification of the posterior longitudinal ligament. Spine (Phila Pa 1976) 35 E359-362.

14. Min JH, Jung BJ, Jang JS, Kim SK, Jung DJ, et al. (2009) Spinal cord herniation after multilevel anterior cervical corpectomy and fusion for ossification of the posterior longitudinal ligament of the cervical spine. J Neurosurg Spine 10: 240-243.

15. Fujibayashi S, Shikata J, Yoshitomi H, Tanaka C, Nakamura K, et al. (2001) Bilateral phrenic nerve palsy as a complication of anterior decompression and fusion for cervical ossification of the posterior longitudinal ligament. Spine (Phila Pa 1976) 26: E281-E286

16. Seichi A, Hoshino Y, Kimura A, Nakahara S, Watanabe M, et al. (2011) Neurological complications of cervical laminoplasty for patients with ossification of the posterior longitudinal ligament-A multi-instituitional retrospective study. Spine (Phila Pa 1976) 36: E998-E1003.

17. Chen Y, Chen D, Wang X, Guo Y, He Z (2007) C5 palsy after laminectomy and posterior cervical fixation for ossification of posterior longitudinal ligament. $J$ Spinal Disord Tech 20: 533-535.

18. Ikenaga M, Shikata J, Tanaka C (2005) Radiculopathy of C-5 after anterior decompression for cervical myelopathy. J Neurosurg Spine 3: 210-217.

19. Iwasaki M, Okuda S, Miyauchi A, Sakaura H, Mukai Y, et al. (2007) Surgical strategy for cervical myelopathy due to ossification of the posterior longitudinal ligament: Part 1: Clinical results and limitations of laminoplasty. Spine (Phila Pa 1976) 32: 647-653.

20. Hirabayashi K, Toyama Y, Chiba K (1999) Expansive laminoplasty for myelopathy in ossification of the longitudinal ligament. Clin Orthop Relat Res 359: 35-48.

21. Tsuzuki N, Abe R, Saiki K, Zhongshi L (1996) Extradural tethering effect as one mechanism of radiculopathy complicating posterior decompression of the cervical spinal cord. Spine (Phila Pa 1976) 21: 203-211.

22. Yonenobu K, Hosono N, Iwasaki M, Asano M, Ono K (1991) Neurologic complications of surgery for cervical compression myelopathy. Spine (Phila $\mathrm{Pa}$ 1976) 16: 1277-1282.

23. Hatta $Y$, Shiraishi $T$, Hase $H$, Yato $Y$, Ueda $S$, et al. (2005) Is posterior spinal cord shifting by extensive posterior decompression clinically significant for multisegmental cervical spondylotic myelopathy? Spine (Phila Pa 1976) 30: 2414-2419. 
Citation: Lau D, Park P (2012) Delayed C5 Palsy after Laminectomy and Fusion for Ossification of the Posterior Longitudinal Ligament. J Spine 1:104. doi:10.4172/2165-7939.1000104

24. Sodeyama T, Goto S, Mochizuki M, Takahashi J, Moriya H (1999) Effect of decompression enlargement laminoplasty for posterior shifting of the spinal cord. Spine (Phila Pa 1976) 24: 1527-1532.

25. Cardoso MJ, Koski TR, Ganju A, Liu JC (2011) Approach-related complications after decompression for cervical ossification of the posterior longitudinal ligament. Neurosurg Focus 30: E12.

26. Sakaura H, Hosono N, Mukai Y, Ishii T, Yoshikawa H (2003) C5 palsy after decompression surgery for cervical myelopathy: review of the literature. Spine (Phila Pa 1976) 28: 2447-2451

27. Tani $S$ (2009) Diagnosis and management of ossification of the posterior longitudinal ligament of the cervical spine. Brain Nerve 61: 1343-1350.

28. Park P, Lewandrowski KU, Ramnath S, Benzel EC (2007) Brachial neuritis: an under-recognized cause of upper extremity paresis after cervical decompression surgery. Spine (Phila Pa 1976) 32: E640-E644.
29. Guthikonda B, Pensak ML, Theodosopoulos PV (2010) Delayed facial palsy after the anterior petrosal approach: case report and review of the literature. Neurosurgery 66: E845-E846.

30. Gianoli GJ (2002) Viral titers and delayed facial palsy after acoustic neuroma surgery. Otolaryngol Head Neck Surg 127: 427-431.

31. Chiba K, Toyama Y, Matsumoto M, Maruiwa H, Watanabe M, et al. (2002) Segmental motor paralysis after expansive open-door laminoplasty. Spine (Phila Pa 1976) 27: 2108-2115.

32. Hasegawa K, Homma T, Chiba Y (2007) Upper extremity palsy following cervical decompression surgery results from a transient spinal cord lesion. Spine (Phila Pa 1976) 32: E197-E202.

33. Kaneko K, Hashiguchi A, Kato Y, Kojima T, Imajyo Y, et al. (2006) Investigation of motor dominant C5 paralysis after laminoplasty from the results of evoked spinal cord responses. J Spinal Disord Tech 19: 358-361. 